\title{
Implications of biostratigraphy in the Himalayan Paleogene Foreland Basin
}

\section{SB Bhatia ${ }^{1 *}$ and ON Bhargava ${ }^{2}$}

\author{
1441 Sector 6, Panchkula-134109, INDIA \\ 2103 Sector 7, Panchkula-234109, INDIA \\ * For correspondence, email: sudhashi0903@hotmail.com
}

The paper discusses the role and significance of biostratigraphy in deciphering the structures, facies models and dating event stratigraphic surfaces of the intricately deformed Paleogene sediments comprising the Subathu, Dagshai and Kasauli formations (Late Thanetian-Early Miocene) of the Surajpur Tectonic Unit of the Himalayan Foreland Basin. The larger foraminifera, particularly the Nummulitdae, which occur in great abundance in distinct foraminiferal bands in the Subathu Formation are chronologically significant and facilitate recognition of Shallow Benthic Faunal Zones (SBZ-Serra-Kiel et al. 1998) throughout the Tethyan Zone, including the Himalayan Foreland Basin (Bhatia and Bhargava 2005, 2006).

In the case of the structurally deformed Paleogene sediments of the Surajpur Tectonic Unit (Mukhopadhyay and Misra, 2005), it is all the more imperative to identify and recognize the biostartigraphically significant foraminifera and other taxa to determine the younging direction of the beds. Failure to do so led Raiverman and Raman (1971), Singh (1996) and Raiverman (2002) to erroneous conclusions by suggesting an inter-tonguing relationship between the various exposed green Subathu (G1-G5) and the red Dagshai sediments (R1-R5) on the Simla-Bilaspur Highway, implying thereby that the G1-R1-G2-R2 ... sequence was towards the younging direction. This concept was soon contradicted by Batra (1989) on the basis of the faunal zones, which were repeated in all the G1-G5 units clearly suggesting that they were all of the same age (Late Cuisian-Early Lutetian) and that the repetition of the red and green beds was due to folding and faulting. Later works of Bagi (1992), Najman et al. (1993) and others confirmed this view. Singh's (1996) work, based on the premise that the increase of the proloculus size in the megalospheric generation (Form A) in larger foraminifera, is of phylogenic significance, is misconstrued in as much as it relies on the proloculus-size increase in a single species-identified by him as Nummulites atacicus, which neither corresponds in size to the types from Europe nor to the Shallow Benthic Zone (SBZ) 8 , Middle Ilerdian, of which it is one of the characteristic zonal fossil. The bulk of larger foraminifera in the exposed Subathu Formation- G1-G5 in the Bilaspur-Simla Highway are of Middle-Late Cuisian (SBZ 11-12) and Early Lutetian age (SBZ 13 =Assilina spira abrardi = Zone III of Batra, identified by him as Assilina blondeaui.

The inter-tonguing concept of green Subathu and red Dagshai was extended to embrace the grey facies of the Kasauli Formation also in the section near Charring Crossing in Dagshai Cantonment (Raiverman 2002, p. 12, figs. 2.1, 2.5c). This would seem to imply that the Kasauli Formation, generally accepted to be of Early Miocene age, is roughly homotaxial with the Early to Middle Eocene Subathu Formation-an untenable stratigraphic situation. We critically examined the Charring Crossing section and did not find any evidence of interfingering between the green and red Subathu (actually the Passage Beds with characteristic molluscs) and the grey beds of the Kasauli Formation. On the contrary, the two are juxtaposed along a thrust plane as evidenced by profuse silckensides observed in all the rocks, particularly the sandy beds exposed in this section. The Subathu Formation along with the overlying Dagshai Formation, exposed north and northeast of the Charring Crossing, was found to have ridden over the Kasauli Formation along a ramp-flat-ramp thrust, which may be designated as the Dagshai Thrust.

In so far as the relationship between the various morphotypes of the Nummulitidae (Nummulites and Assilina and various paleofacies models) are concerned, the work by Luterbacher (1984) in Southern Pyrenees shows a correlation between morphological characters (size and shape, whether lenticular or flat discoidal), classified into four morphotypes and the established facies models in the Paleogene of the Pyrenees. Our work in the Kaushalia River section shows that the beds of the lowermost SBZ 10 (Early Cuisian) containing Nummulites planulatus and N. burdigalensis burdigalensis were deposited in a beach, prodelta setting, while those of SBZ 11 and 12 (Middle to Late Cuisian) with abundant A. laxispira, A. cuvillieri, besides bryozoa, crabs etc., in a lagoon to bay carbonate shoal setting, and those of SBZ 13 (Early Lutetian)A. spira abrardi bed (flat discoidal $>8 \mathrm{~mm}$ diameter) in a beach, shore face, near shore shoal environment.

The larger foraminiferal fauna thus corroborates the views expressed three decades earlier on sedimentological criteria by Singh (1978) that most of the Subathu sediments were laid down in shelf mud, tidal flats, and coastal sand bars. This view has stood the test of the time as confirmed by several workers from the homotaxial beds in Jammu, Hazara-Kashmir Syntaxis and Nepal. These homotaxial beds were deposited in a shallow, wave and storm dominated tidally influenced lagoon/barrier beach with near shore carbonate-shoal setting.

The above conclusions are in stark contradiction to the contention of Bera et al. (2008) of documenting for the first time large varieties of basinal turbidites in the Subathu-an interpretation that is not corroborated by sedimentological and paleontological evidences. The occurrence of hummocky crossbedded sandstones (Late Cuisian) immediately below the $A$. spira abrardi bed in the Kaushalia River section (Bagi 1992) and in the oyster-bearing beds in the Jammu sector (Singh and Andotra, 2000) testify to frequent storm events in the Subathu basin. We are also in strong disagreement with the conclusion of Bera et al. (2008) that "Fixing an age for the termination of marine beds, based on reworked fossils (e.g. A. spira) in calciturbidite units is not justifiable and the upper limit of the Subathu Formation 
must be significantly younger than ca $44 \mathrm{Ma}$." In support of the above contention, Bera et al. (2008) have shown the occurrence of A. spira in a calciturbidite bed at the base of the black grey Subathu shale in most of their sections, which is hypothetical, factually incorrect and militates against the basic principles of stratigraphy. The surmise of Bera et al. (2008) regarding the upper age limit of Subathu is not borne out by the fossil records in the overlying Passage Beds, which delimit the termination of HST, including the Passage Bed around ca $40 \mathrm{Ma}$ (Bhatia and Bhargava 2005). The A. spira abrardi bed (SBZ 13) in the Subathu Formation in all the sections occurs in the same chronological order above the beds containing foraminifera of Cuisian age (SBZ 12) as it does elsewhere in the Tethyan Zone (European biozonation), hence could not be reworked by any stretch of imagination.

In so far as the Event Stratigraphic framework is concerned, the entire Subathu sequence including the coal and carbonaceous shale at the base and the Passage Beds at the top represent Highstand Systems Tract (HST), the maximum flooding surface (MFS) is seen in sections where the base is exposed, viz., Jammu, Kakra and other sections and is represented by the occurrence of limestone beds containing Daviesina garumnensis (Bhatia and Bhargava 2005, 2006) representing SBZ 4 of Late Thanetian age.

We concur with Bera et al. (2008) that the ubiquitous white sandstone bed in the Kaushalia River and other sections, occurring at the top of the Passage Beds with a sharp contact, is of marine origin and that it represents the Falling-Stage Systems Tract (FSST) in the Event stratigraphy framework. However, we disagree with their age assignment of $31 \mathrm{Ma}$ to the white sandstone and of $28 \mathrm{Ma}$ to the overlying Dagshai, as none of these dates are corroborated with the fossil record (Bhatia and Bhargava 2005).

References

Bera MK, A Sarkar, PP Chakraborty, RS Loyal and P Sanyal. 2008. Marine to continental transition in Himalayan Foreland. Geological Society of America (In Press, available On Line)

Bhatia SB and ON Bhargava. 2005. Regional Correlation of the Paleogene sediments of the Himalayan Foreland Basin. Palaeontological Society of India, Special Publication 2: 105-123

Bhatia SB and ON Bhargava. 2006. Biochronological continuity of the Paleogene sediments of the Himalayan Foreland Basin: paleontological and other evidences. Journal of Asian Earth Sciences 26: 477-487

Bhatia SB and ON Bhargava. 2007. Reply to Y.Najman, 2007, Comments on "Biochronological continuity of the Paleogene sediments of the Himalayan Foreland Basin: paleontological and other evidences"Bhatia, S.B. and Bhargava, O.N., 2006, Journal of Asian Earth Sciences. 26,477-487. Journal of Asian Earth Sciences 31: 87-89

Luterbacher H 1984. Palaeoecology of foraminifera in Paleogene of Southern Pyrenees. Bentho's 83. Second International Symposium Benthic Foraminifera April 1983 p389-392

Mukhopadhyay DK and P Misra. 2005. A balanced cross section across the Himalayan frontal fold-thrust belt, Subathu area, Himachal Pradesh, India: thrust sequence, structural evolution and shortening. Journal of Asian Earth Sciences 25: 735-746 